\title{
A Short Comment on Skip Hills' Remarks
}

\section{Daniel Tröhler}

University of Luxembourg

\begin{abstract}
$A^{\mathrm{T}}$ T the end of his thoughtful comment Professor Hills refers to Alasdair MacIntyre's distinction between practices and institutions. According to MacIntyre, institutions are a necessary precondition for certain social practices, but at the same time they are somehow foreign to these practices, too. This foreignness of the institution from the practice is described as potentially corrupting the latter. Therefore, MacIntyre argues that the development of virtue operates as a safeguard against the corrupting influence of the institution.

MacIntyre transfers the concept of virtue, as it is found in the language of republicanism, to institutional analysis. This language was first formulated in the political theories of Xenophon and Aristotle and has evolved during the centuries. The role of public virtue was fostered against the fear of corruption, but - if I am not mistaken - not of corruption of the power of institutions, but of the people with power within institutions. While classical republicanism kept postulating virtue as a core aim of education in order to maintain the public welfare, the skepticism towards too much power was the very reason for the separation of powers in the American Constitution of 1787. Rather than trust in education, it was distrust of people in positions of power that underwrote this successful concept. Ever since this time, the question of control has become a core issue with respect to people in power, and against this background we indeed live in a time After Virtue (MacIntyre 1981).

The question remains, then, why people were provided with education at all. To put it differently: Why was public education, of all things, created after the idea of the (political) separation of power had been implemented in the American and French Constitutions and to what degree was/is public education capable of meeting its stated obligations? There is little doubt that in different times and places people had different ideas about the meaning of public education. The rational ideology of the French philosophers after 1789 with its ideal of the enlightened citoyens framed a different system of public education from the school system of the United States, whose ideal was the virtuous citizen. This ideal still remained alive in spite of the American Constitution. Different, too, was the German system with its Lutheran ideology of the Bürger as primarily subjects. And over the course of the decades, culminating at
\end{abstract}


the end of the nineteenth century, as associated ideologies, curricular settings, and pedagogies changed, education became dreadfully nationalistic in most of the countries. In this context, it is understandable how the German Kaiser at the great school conference in Berlin in December, 1890 could demand: "A national basis is wanting. The foundation of the Gymnasium must be German; we must raise national young Germans and not young Greeks and Romans" (Wilhelm II, 1891, p. 72).

Against this background of high(est) expectations it is true that all educational reforms were output orientated. People expected children to come out of school as products of its preordained design. What has been changed, however, is the fundamental conviction of how schools can be governed or - to use the popular term - steered. Until recently the output orientation went along with input steering. Reform was targeted at better text books, better teacher education, smaller classes, more leisure time, improved pedagogy etc. However, the expectations towards schooling were of a kind that disappointments were the natural result? reactions. Whether or not some of these reforms lowered the quality of public education may be the issue of a different discussion, but no educational reform was started with the aim of worsening the school system. Usually, if people get engaged, they believe that whatever they do will lead to a better future. Let us just recall what Edward Lee Thorndike - today labeled as behaviorist and thus rather criticized - said: "The arts and sciences serve human welfare by helping man to change the world, including man himself, for the better. The word education refers especially to those elements of science and art which are concerned with changes in man himself" (Thorndike, 1914, p. 1).

What really has changed in recent times is that the output orientation of the school system was joined by the idea of output steering. The basic idea is that schools are partly autonomous so that they are free to achieve the goals set by experts, and there is a system of incentives to help the schools doing well in pursuing the goals. Compared to the idea of the virtuous citizen or the rational citoyen or the Lutheran subject these new goals are rather meager - but measurable. But mindless addiction to measurement is itself not purely rational for while test results are usually connected to the national economic growth, democracy and welfare, the language remains the one of salvation. That is why, among many others, Skip Hills bemoans the new reforms to be financially motivated. However, neither the World Bank nor the OECD has ever proven that the improvement of test scores in a mother tongue will foster economic growth or public welfare. They have failed, too, to prove that better test sores will enhance democracy. And they will have a hard time doing so. The 2006 PIRLS-study had as its top three countries and one Canadian province, the countries not really famous for their democracy. First was Russia, second Hong Kong, and fourth Singapore. In contrast, the province of Alberta with its democratic control of the school system (elected school boards) was placed after Hong Kong and before Singapore.

It is obvious that "the school" does not always "do" what it is expected to do and we should be grateful about that rather than moan about it. There is of course no reason why we should not improve schooling but we have, I believe, already had too many suggestions of how "the school" should be: moral, national, child-centered, 
rational ... It is time, I would say, that first we should know much more about idiosyncrasies of the system and its dependence not so much on reformers but on the common public and its dominant culture, derived from taken-for-granted assumptions resulting from experiences shared over decades or even centuries. In order to do this we need to critically test the dominant theories of the school system, be it NeoInstitutionalism or the idea of the "grammar of schooling" or any other theory trying to understand peculiarities of the system. To do so I do not see any alternative other than to be empirical — not empiristic (Tröhler, 2007) — in the sense of observing how the school systems have reacted towards deeper crisis or changes in the collective cultures. The setting, then, must be historical and comparative, not limiting itself to numbers and scales, but rather including discourse as an empirical fact.

Against this background I appreciate even more our discussion in the transnational journal Encounters on Education / Encuentros sobre Educación / Rencontres sur l'Éducation. If we start to understand ourselves and our ideas as part of the cultural context — even if we are critical about it — we will by virtue of international discussions learn more, especially about ourselves, our advantages and limits. Virtue in this sense is not in the past, but is more tightly bound to our historical setting.

\section{References}

Thorndike, Edward Lee (1914): Educational Psychology. Briefer Course. New York 1914: Teachers College, Columbia University.

Tröhler, Daniel (2007): Philosophical Arguments, Historical Contexts, and Theory of Education. Educational Philosophy and Theory 39 (2007) (1), pp. 10-19.

Wilhelm II (1891): Eröffnungsrede [Opening speech]. In Verhandlungen über Fragen des höheren Unterrichts. Berlin, 4. bis 17. Dezember 1890. Im Auftrage des Ministers der geistlichen, Unterrichts- und Medicinal-Angelegenheiten (pp. 70-76). Berlin. 